\title{
Legal Reform Need Not Come First: Merit-Based Civil Service Management in Law and Practice
}

\author{
Forthcoming in Public Administration
}

\section{Author details:}

Dr. Christian Schuster

Lecturer in Public Management

School of Public Policy

University College London

29/30 Tavistock Square, London WC1H 9QU, United Kingdom

Email: c.schuster@ucl.ac.uk

Tel: +44(0) 7428400881

\section{Acknowledgments:}

The author would like to thank Dominika Janidzarova, Omar Estefan and Miranda Simon for their excellent research assistance, as well as participants at the 2015 ECPR Joint Sessions and 2015 EPSA Conference for helpful comments. 


\title{
Legal Reform Need Not Come First: Merit-Based Civil Service Management in Law and Practice
}

\begin{abstract}
Introducing merit recruitment of public servants is a central good governance reform. To move towards merit in practice, legislation which mandates merit recruitment is considered a necessary but insufficient first step by many scholars and practitioners. Merit-based civil service legislation should thus be sought before reform in practice. This paper challenges this reasoning. It argues that merit laws are neither sufficient nor necessary: they leave the incumbent's possibility frontier for patronage and meritocracy in practice unaffected. Large and small-n evidence supports this assertion. Analyses of an original dataset of coded civil service legislation in 117 countries from 1975 to 2015 suggest that countries can attain meritocratic recruitment with and without legal merit requirements. Subsequently, a comparison of Paraguay and the Dominican Republic provides micro-evidence for the underlying mechanism. Conventional wisdom about the sequencing of governance reforms in developing countries may thus be misleading: legal reform need not come first.
\end{abstract}

\section{Introduction: The Holy Grail of Merit Reform}

Introducing merit-based civil service management in patronage states is a central good government reform (Dahlström, Lapuente and Teorell, 2012). In patronage states, political and personal criteria largely determine bureaucratic recruitment and careers. By contrast, in merit-based states, the most professionally qualified candidates for recruitment and promotion are selected. Giving pride of place to merit reforms is motivated by their development impact. Merit-based civil services are empirically associated with economic growth (Evans and Rauch 1999); lower poverty (Henderson, Hulme, Jalilian and Philips, 
2007); reduced corruption (Dahlström, Lapuente and Teorell, 2011; Charron, Dahlström, Fazekas and Lapuente, 2016; Oliveros and Schuster, 2017); and greater democratic stability, to name a few (Cornell and Lapuente 2014).

Yet, for many developing countries, meritocratic civil services remain elusive. According to expert survey data, political criteria trump merit criteria in personnel recruitment in 64 percent of non-OECD countries - despite recurrent reform attempts (calculated from Dahlberg, Dahlström, Sundin and Teorell, 2013). The World Bank (2008), for instance, lent US $\$ 422 \mathrm{~m}$ per year for civil service and administrative reform in 2000-2006 - yet without measurable impact. Patronage systems featured among the prime reform obstacles.

How can patronage systems be reformed? One prominent response has been the adoption of merit laws. Such laws typically "require selection for the appointment to the Civil Service to be on merit on the basis of fair and open competition." (UK Civil Service Commission, 2012, p. 2). Fair and open competition thereby requires advertised vacancies and the selection of the (professionally) best applicants in competitive written and/or oral examinations (in short: competitive examinations). ${ }^{1}$ As detailed below, practitioners frequently rely on the adoption of such merit laws to advance merit in practice. Scholars in turn have argued that, while merit laws are insufficient to bring about merit in practice, they are a necessary first step.

This paper goes one step further in the critique of merit laws: it argues that such laws are neither sufficient nor necessary for merit in practice. Instead, merit laws leave the incumbent's possibility frontier for patronage and meritocracy in practice unaffected. The paper provides large and small-n evidence for this argument. First, data from an original dataset of coded civil service legislation in 117 countries from 1975 to 2015 - the largest cross-country coding of civil service legislation in the literature to-date - suggests that 
countries can attain meritocratic recruitment with and without a merit requirement in law or constitution. Subsequently, a comparison of Paraguay and the Dominican Republic, which draws on 130 semi-structured interviews, provides micro-evidence for the theorized mechanism which enables merit in practice without merit legislation. Conventional wisdom about the sequencing of governance reforms in developing countries may thus be misleading: legal reform need not come first.

\section{Merit Laws and Merit Practice in the Literature}

Merit reforms in patronage states are - as donor-supported governance reforms in the developing world at-large - frequently characterized by a 'bias toward formal institutions' (Andrews 2013, p. 8; see also Pritchett, Woolcock and Andrews, 2010, among many). Practitioners often advocate introducing merit legislation, at times going as far as considering legal reform an 'objective in itself.' (Verheijen 2000, p. 26)

Relative to practitioners, scholars have been somewhat less sanguine about merit laws. In their accounts, merit laws are necessary but insufficient for merit in practice. To illustrate, scholar have posited that: 'the enactment of civil service legislation does not automatically lead to the institutionalization of merit;' 'the fate of career civil service reform initiatives is generally determined after they have been legislated'; and 'the adoption ... of civil service laws ... does not necessarily lead to the de-politicization of civil services' (Grindle 2010, p. 2; Lapuente and Nistotskaya 2009, p. 443; Meyer-Sahling 2006, p. 693)

This insufficiency of merit legislation is variably explained by four mechanisms. Capacity shortfalls in patronage states may complicate implementation (see, among many, Polidano 2001). Merit laws may leave incumbents with 'formal political discretion:' patronage permitted by law through loopholes such as temporary contracts or parallel institutions (Meyer-Sahling 2006, p. 693). Incumbents may retain patronage by resorting to 
what this paper terms façade meritocracy: the manipulation of seemingly meritocratic examinations to favour preferred candidates. And lastly, incumbents may ignore merit laws: the absence of rule-of-law contexts are characteristic of patronage states (Charron, Dahlström and Lapuente, 2012; Fukuyama 2014, p. 51). Public servants - including those in charge of legal compliance - are appointed based on political and personal criteria. Correspondingly, their decision-making typically prioritizes political-personal over professional-legal criteria. Legal violations of merit laws thus tend to go unpunished, turning them into 'dead letter[s]' (Goetz 2001, p. 1036).

The latter three mechanisms are often at play due to 'window dressing' attempts by incumbents: the appearance of reform progress without reform in practice (Andrews, 2013). Merit legislation can thus lead to formal institutions which are merely 'ceremonial' (Meyer and Rowan, 1977, p. 340), enabling developing countries to assume the forms of modern states without functioning like them (Pritchett, Woolcock and Andrews, 2010). As a corollary, implementing legal merit requirements is in practice optional to incumbents in patronage states.

Consequently, merit legislation is argued to be insufficient to bring about merit in practice. At the same time, however, it is argued to create a formal institution which, through its 'activation,' permits incumbents to move towards meritocratic civil service management in practice (cf. Levitsky and Murillo 2013, p. 103). In other words, merit laws are considered necessary, even if insufficient for reform in practice.

This argument carries an important normative implication for the sequencing of civil service reforms. If merit legislation is a necessary condition for reform in practice, practitioners should seek merit legislation before seeking advances in meritocratic civil service management in practice. Taken at face value, this normative implication provides one 
important rationale and justification for the frequent reliance on merit laws in civil service reform strategies.

The argument developed in the next section will challenge this line of reasoning: legal reform need not come first.

\section{Why Merit Laws Are Not Necessary for Merit in Practice}

As shall be argued, merit legislation is not only insufficient but also unnecessary for merit reform in practice. To explain why merit laws are not necessary for merit in practice, one of the mechanisms underlying the insufficiency of merit legislation can be built on and extended.

To construct the argument, recall that merit laws are civil service laws mandating open and competitive procedures for personnel selection. In their absence, personnel selection will be governed by other procedures. Such procedures may or may not prohibit merit-based personnel selection. Irrespective of whether they do, however, introducing merit is - as shall be argued - in practice optional to incumbents.

Consider, first, an incumbent in a patronage state facing a legal prohibition of meritbased personnel selections. Whether to comply with this legal prohibition or violate it by introducing merit recruitment is, in practice, optional to the incumbent. As aforementioned, (un)rule of law contexts are characteristic of patronage states (see Charron, Dahlström and Lapuente, 2012; Fukuyama 2014, p. 51). In other words, incumbents may non-comply with both good and bad governance legislation at will in patronage states. One dimension of good governance in practice - merit-based personnel selections - may thus emerge despite bad governance legislation prohibiting such practices. Somewhat ironically, the very lack of one good governance dimension in patronage states - the absence of strong rule of law and 
concomitant prevalence of informal institutionality (cf. Helmke and Levitsky, 2006) - can thus facilitate the emergence of meritocracy as another good governance practice.

Empirically, however, explicit legal prohibitions of merit may be expected to remain rare given their window dressing costs. In fact, a review of current public personnel and labour legislation in Spanish-speaking Latin America by the author revealed no instance. In such contexts, a second mechanism enabling merit in practice without merit legislation is activated: the introduction of meritocratic examinations as a residual right of incumbents. As, in the absence of legal merit requirements, laws neither demand merit nor prohibit it, merit in practice is optional to incumbents.

With or without merit laws, meritocratic civil service management thus tends to be $d e$ facto optional for incumbents in patronage states. Consequently, merit laws do not affect the incumbent's possibility frontier for patronage and meritocracy in practice. This challenges a key practitioner rationale for advancing merit legislation: incumbents may advance merit in practice without seeking legal reform first.

That incumbents are able to advance merit in practice without seeking legal reform first, of course, does not imply that they face incentives to do so. ${ }^{2}$ In fact, we would expect this scenario to be the exception. Where possible, incumbents are likely to prefer seeking legal reform first. As a signal of reform commitment to external stakeholders, legal reform may enhance incumbent legitimacy in patronage states irrespective of merit practice (cf. Andrews, 2013). Moreover, specifying a merit requirement in law may potentially facilitate reform implementation by aligning merit practice with formal legal requirements. While incumbents may thus be expected to, typically, seek legal reform first, they may find themselves in contexts in which they wish to advance merit practice, yet are unable to pass legal reform. Consider, for instance, an executive who wishes to advance merit practice, yet does not count on a majority in a hostile legislature to pass civil service legislation. 
Alternatively, consider an executive who wishes to advance merit practice from the get-go when coming to power, without awaiting the typically lengthier process of approval of merit legislation. In such contexts, incumbents may be expected to seek merit practice before legal reform. This holds not least as such reforms need not be short-lived. Extrapolating from research on informal institutions (cf. Helmke and Levitsky, 2006), reform institutionalization in patronage states with high levels of informality arguably depends principally on whether competitive examinations replace patronage appointments as the prevalent (informal) norm for personnel decisions.

The empirical expectation is thus clear: reform in practice occurs on occasion before legal reform, yet this reform sequencing is the exception rather than the rule. The next sections will assess the empirical validity of this claim. Before doing so, it is worth clarifying what this claim is not connoting: that merit laws do not impact merit practice. Even if merit laws are not necessary for merit in practice - which undoes one important rationale for relying on them - they might shape merit practice. The conclusion will return to this separate empirical question.

\section{Merit Laws are neither Necessary nor Sufficient: Evidence from an Original Civil Service Legislation Dataset}

Assessing whether merit laws are necessary or sufficient for merit in practice requires data on merit in law and practice. This data shall be described first. Subsequently, the necessity and sufficiency of merit legislation for merit practice is empirically assessed.

\section{Data on Legal Merit Requirements.}

To measure legal merit requirements, the existing literature is of limited avail. On an upside, it does offer constitutional data: the Comparative Constitutions Project (CCP) (2015) codes 
for up to 142 countries whether 'the constitution include[s] provisions for the meritocratic recruitment of civil servants.' Data for a subset of countries is available since 1789. While a legal merit requirement can, at times, stem from a constitutional stipulation, it may, of course, equally - and much more typically as illustrated in figure 1 below - stem from the adoption of merit legislation. Merit law data does not exist in the literature, however.

To remedy this data gap - and enable an empirical assessment of this paper's argument - an original dataset of merit-based civil service legislation was assembled. With support from a team of multi-lingual research assistants, merit requirements in civil service laws were coded for the period 1975-2015. Thanks to greater accessibility of more recent legislation, the number of countries for which the presence or absence of legal merit requirements could be coded increases from 85 in 1975 to 117 in 2015 in the dataset, with 4174 country-year observations in total for 1975-2015 (figure 1). To our knowledge, this is the largest dataset of coded civil service legislation to-date. The coding criteria and procedure are described in the Appendix. The countries included in the dataset were sampled from the 126 countries for which data on merit practice is available from either the 2008-2012 or the 2014-2015 Quality of Government (QoG) expert survey on the structure of government (Dahlberg et al. 2013; Dahlström et al. 2015).

\section{Data on Merit in Practice.}

Merit in practice is measured by drawing on data from two sources.

The first and principal measure of merit in practice comes from the QoG global expert survey. 107 and 121 countries with at least three expert respondents each were covered in two survey waves (Dahlberg et al. 2013; Dahlström et al. 2015). Merit in practice is measured with the survey question 'When recruiting public sector employees, the skills and merits of 
the applicants decide who gets the job?' Countries score, on average, slightly above the midpoint of the 1-7 scale for this question (4.03, with 7 being the most meritocratic) (table 1).

The second measure for merit in practice comes from the Varieties of Democracy (VDem) project. V-Dem covers 173 countries from 1900 to 2012, based on estimates from over 2,500 country experts (Coppedge et al., 2016). Contrary to the QoG measure, it thus permits an analysis of temporal change. At the same time, its construct validity is weaker. V-Dem asks experts to assess the extent to which a country's public administration is characterized by impartiality. ${ }^{3}$ Empirically, impartiality and meritocracy are close proxies: the V-Dem measure is strongly and significantly $(\mathrm{r}=0.71)$ correlated with the QoG meritocracy measure. Theoretically, this should not surprise: merit-based civil services and impartial fulfillment of duties are twin features of Weberian bureaucracies. The variables' strong correlation and the empirical expectation of their concurrence enhance confidence that the V-Dem may serve as a rough proxy for meritocracy in a suggestive inter-temporal analysis.

With this in mind, both measures are used in the empirical analysis below. The measures yield congruent results: merit laws are neither necessary nor sufficient for merit in practice.

TABLE 1 Summary Statistics

\begin{tabular}{|c|c|c|c|c|c|c|c|}
\hline Variable & Data Source & $\begin{array}{c}\text { Years } \\
\text { included }\end{array}$ & Obs & Mean & Std Dev & Min & Max \\
\hline Merit in Law & $\begin{array}{c}\text { Author's Merit Law } \\
\text { Dataset }\end{array}$ & $1975-2015$ & 4174 & 0.56 & 0.50 & 0 & 1 \\
\hline $\begin{array}{c}\text { Merit in } \\
\text { Constitution } \\
\text { for countries with } \\
\text { coded merit laws) }\end{array}$ & CCP (2015) & $1975-2013$ & 2374 & 0.18 & 0.39 & 0 & 1 \\
\hline $\begin{array}{c}\text { Merit in Practice } \\
\text { (QoG) }\end{array}$ & $\begin{array}{c}\text { Dahlberg et al. (2013) } \\
\& \text { Dahlström et al. } \\
\text { (2015) }\end{array}$ & $\begin{array}{c}2014 / 15 \\
\text { or, in its } \\
\text { absence, } \\
2008 / 12\end{array}$ & 126 & 4.03 & 1.22 & 1.00 & 6.67 \\
\hline $\begin{array}{c}\text { Merit in Practice } \\
\text { (V-Dem } \\
\text { Impartiality Proxy) }\end{array}$ & $\begin{array}{c}\text { Coppedge et al. (2016) } \\
1975-2012\end{array}$ & 3344 & 2.28 & 1.07 & 0.05 & 3.99 \\
\hline
\end{tabular}




\section{Merit in Law and Practice.}

In terms of their legal frameworks alone, countries made great strides towards merit since 1975. In 1975, only a third of coded countries - 28 in total - counted on merit laws. Over the next fifteen years, until 1990, this share increased incrementally to 38 percent (38 countries). From then onward, merit laws proliferated, to 67 percent of coded countries (71 in total) in 2000 and 80 percent of coded countries (94 in total) in 2015. When additionally considering constitutional merit requirements - which might oblige incumbents to recruit based on merit even where merit laws are not adopted - the figure changes only marginally, adding one country since 2005 , for instance. While merit protections in constitution feature in 18 percent of country-year observations for which constitutional data is available, in only 2 percent of these observations did countries not also have merit legislation. In other words, almost all countries which protect merit in their constitutions also adopt merit laws (figure 1).

FIGURE 1. The Proliferation of Merit-Based Civil Service Legislation (1975-2015)

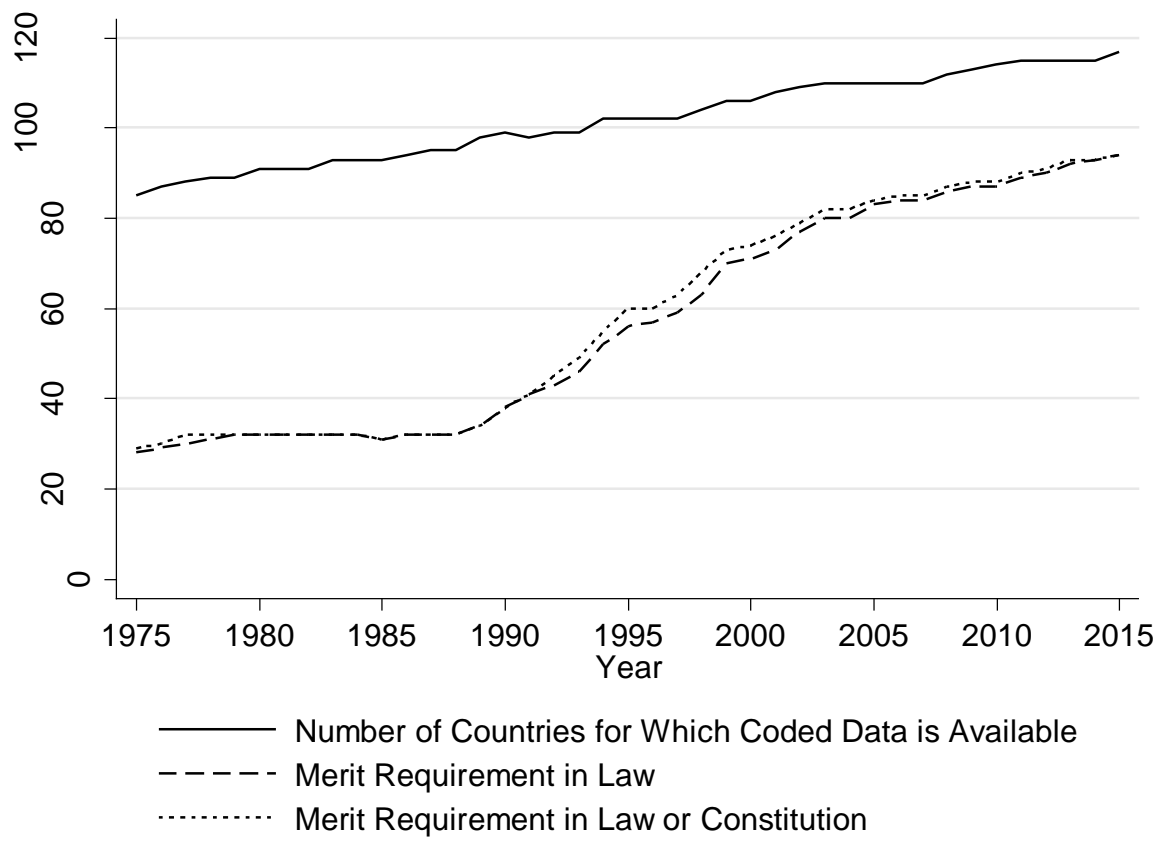

Data sources: author's merit law dataset and CCP (2015) 
In sum then, the share of countries with merit laws on the books has more than doubled in the last forty years. With the rise of the good governance agenda in the 1990s, the pace of merit law adoption has accelerated.

As illustrated in figure 2, however, this proliferation of merit legislation has not been a sufficient condition for meritocracy in practice. In fact, the extent of merit in practice as measured by the QoG survey is statistically indistinguishable between countries with and without legal merit requirements, with both hovering around the midpoint of the scale (at 4.00 and 4.06 respectively). This provides large-n evidence for qualitative assertions in previous studies that merit laws by themselves are insufficient to achieve merit in practice.

FIGURE 2. Merit in Practice with and without Legal Merit Requirements (2015)

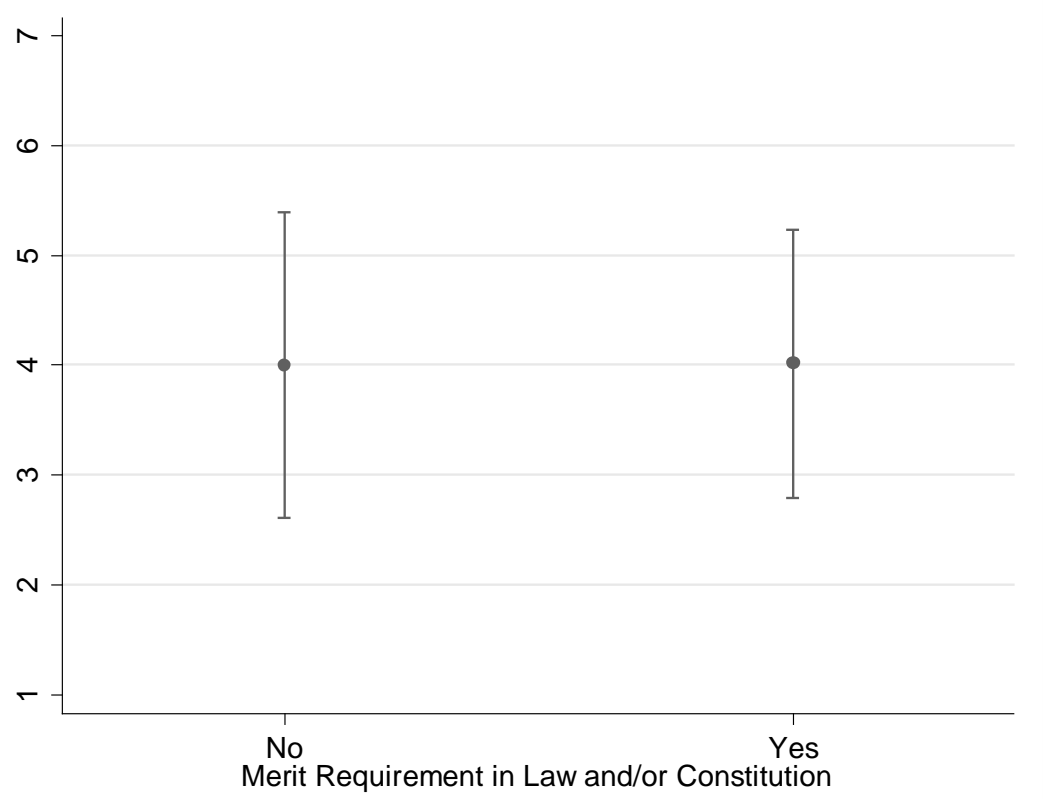

Data sources: author's merit law dataset, CCP (2015), Dahlberg et al. (2013) and Dahlström et al. (2015)

Congruent with this paper's argument, a frequency distribution of the data additionally suggests that merit legislation is not necessary for merit in practice. As illustrated in figure 3, a number of countries score high on merit in practice in the QoG survey data without having had a legal merit requirement in place in any year between 1975 and 2015. 


\section{FIGURE 3. Frequency Distributions of Merit in Practice and Legal Merit Requirements}

Merit in Practice without Merit Legislation

(1975-2015)

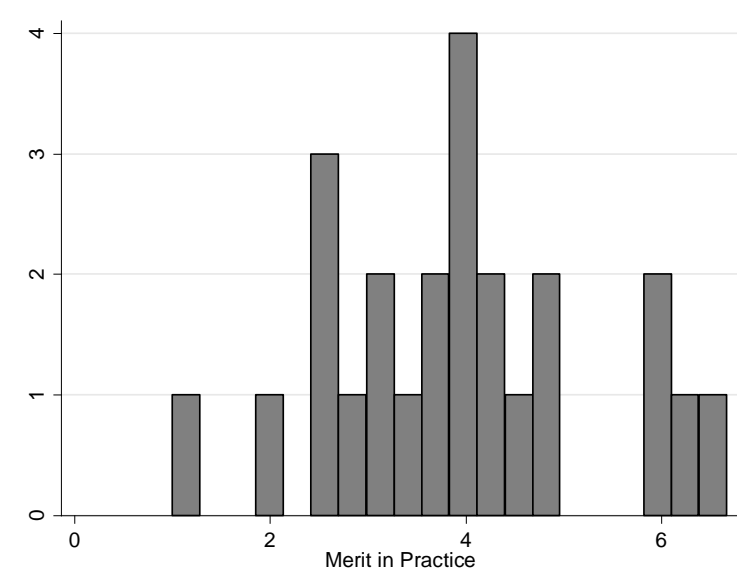

Merit in Practice with Merit Legislation (in at least one year in 1975-2015)

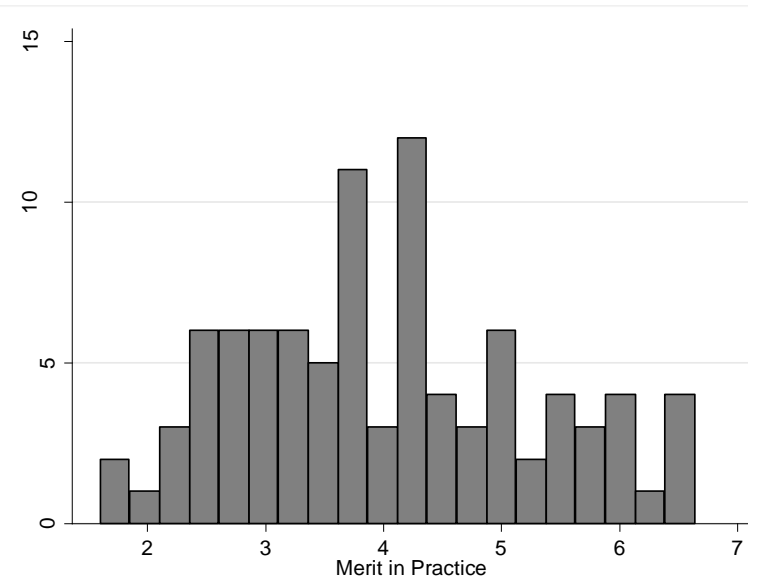

Data sources: author's merit law dataset, CCP (2015), Dahlberg et al. (2013) and Dahlström et al. (2015)

Of course, countries which score high on merit in practice despite not having had a legal merit requirement in place over the previous 41 years could have introduced merit in practice prior to 1975 , when the coding of merit laws commenced. V-Dem data is thus drawn on to provide suggestive evidence that changes in meritocracy in practice between 1975 and 2012 may occur with and without legal merit requirements. In particular, if countries moved towards meritocracy in practice in 1975-2012 without having had a legal merit requirement in place in the same period, confidence in the assertion that merit legislation is not necessary for merit in practice would be further enhanced. ${ }^{4}$

To contextualize this analysis, note that meritocracy in practice - as proxied by the VDem measure - has progressed less in 1975-2012 than meritocracy in law. As illustrated in figure 4, the average V-Dem score improved from 1.85 to 2.4 (on a scale from 0 to 4 ) for countries with coded civil service legislation. Almost all of this increase - from 1.85 to $2.33-$ occurred prior to the 1990s for countries in the sample, however, thus preceding the widespread adoption of merit legislation. 
FIGURE 4. Evolution of Merit Legislation vs. Practice (V-Dem Proxy) in 1975-2015

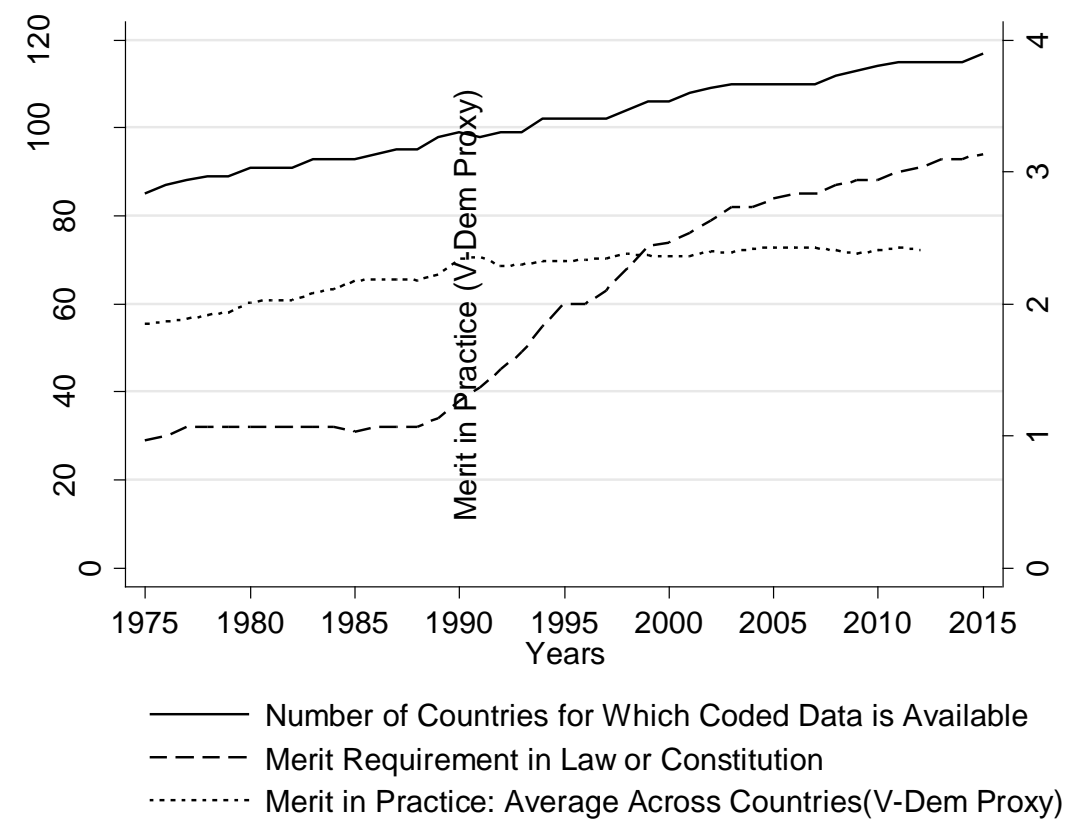

Data sources: author's merit law dataset, CCP (2015) and Coppedge et al. (2016)

As theoretically predicted, progress was thereby made by countries with and without meritbased civil service legislation. 11 countries did not count on a legal or constitutional merit requirement in any year in 1975-2012, and had coded data available for all years in the period. 4 of these 11 countries - Paraguay, Uganda, Iceland and Senegal ${ }^{5}$ - improved their VDem scores in the period (figure 5). Similarly, 48 countries which counted on a legal and/or constitutional merit requirement in at least one year in 1975-2012 improved their V-Dem scores, while 23 did not. 
FIGURE 5. Changes in Merit in Practice and Legal Merit Requirements

Merit in Practice Change without Merit

Legislation in any year in 1975-2012

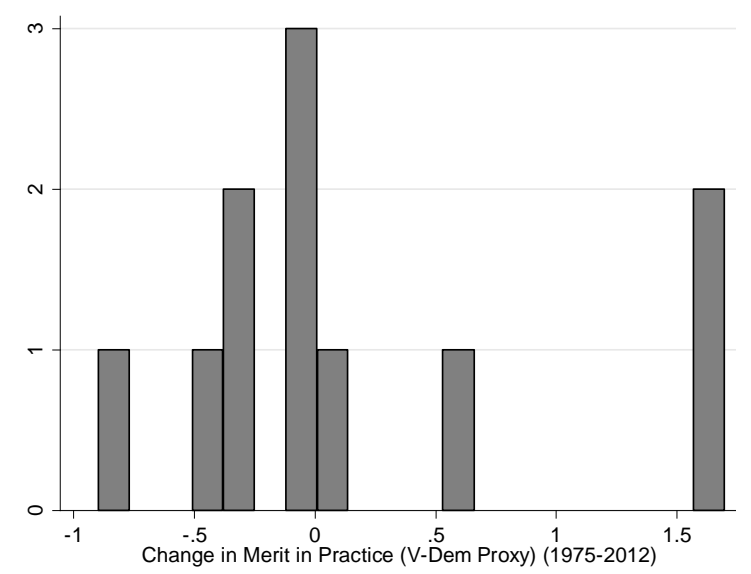

Merit in Practice Change with Merit Legislation in at least one year (1975-2012)

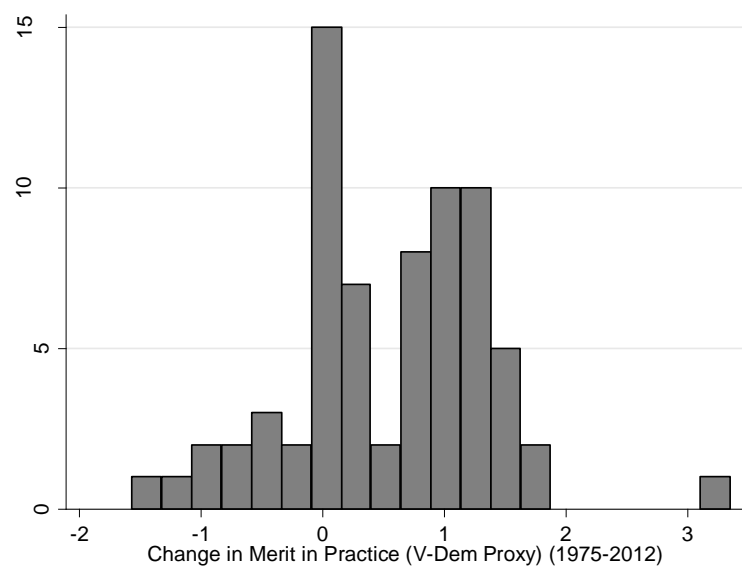

Data sources: author's civil service legislation dataset, CCP (2015) and Coppedge et al. (2016)

Analyses of both V-Dem and QoG data thus suggest that merit-based civil service legislation is neither sufficient nor necessary for meritocratic civil service management in practice. The large-n data, of course, leaves unresolved whether the mechanisms theorized in this paper can account for the lack of necessity and sufficiency of merit laws. These mechanisms are thus assessed qualitatively next.

\section{Merit Laws are neither Necessary nor Sufficient: Evidence from Paraguay and the Dominican Republic}

To assess the mechanisms (de)linking merit laws from merit practice, two cases were sought with comparable merit reform implementation capacity, yet contrasting legal merit requirements. These case selection criteria yielded reforms in Paraguay under President Fernando Lugo (2008-2012) and the Dominican Republic under President Leonel Fernández (2004-2012). The two countries are archetypical patronage states with similarly low bureaucratic capacity, weak rule of law, similar levels of technical and financial assistance 
from international organizations and the same merit reform blueprint, the Latin American Civil Service Charter (see Schuster, 2015, p. 78 for a more detailed account of similarities).

While comparable in terms of their implementation capacity, legal merit protections differ starkly between the two cases. The DR demands merit in law and constitution; Paraguay's legal merit requirement is suspended in court and thus not in force. The introduction of merit-based personnel practices with and without merit laws may thus be contrasted. As shall be shown, merit failed to advance despite the presence of a legal merit requirement (DR); and advanced despite the absence of such a requirement (Paraguay). Congruent with one of the theorized mechanisms, Paraguayan reformers exploited legal permissiveness to advance merit in practice. With no legislation demanding or prohibiting meritocracy, the Ministry of Civil Service could assist line institutions to advance merit in practice at will.

To substantiate these conclusions, data collection in the two cases comprised reviews of legislation; requests for data on merit-based examinations to state institutions; and 130 semistructured interviews -65 in each country. Two protocols were administered: one on merit reform processes and one measuring merit in practice through coded expert estimates. The expert survey provided estimates of substantively competitive - and thus merit-based examinations for public sector positions. The burden on these estimates is limited: they serve to triangulate official data on merit-based examinations. Façade merit reforms could thus be detected.

Experts provided estimates for fifteen typical state institutions in five policy areas. These accounted for 74 (Paraguay) and 51 (DR) percent of public employment (see Schuster, 2015, p. 284 for details of included institutions). In total, 103 institutional-level estimates were obtained. Institutional means, weighted by the number of public employees, were averaged to obtain country-level means. 
This is a second-best: patronage as a phenomenon of 'covert politics' cannot be estimated precisely (Müller 2000, p. 141). Poor recall, judgment error and strategic bias all threaten estimate validity. To counteract these threats, at least five experts were surveyed per policy area; varied backgrounds were sought (figure 6); and, as noted, expert estimates were triangulated with official examination figures. Enhancing confidence in validity, estimates varied little across respondents; linearized standard errors stood at 0.02 (DR) and 0.05 (Paraguay). Moreover, expert estimates coincided with results from official data on merit examinations.

\section{FIGURE 6 Respondent types across interview protocols $(n=130)$}

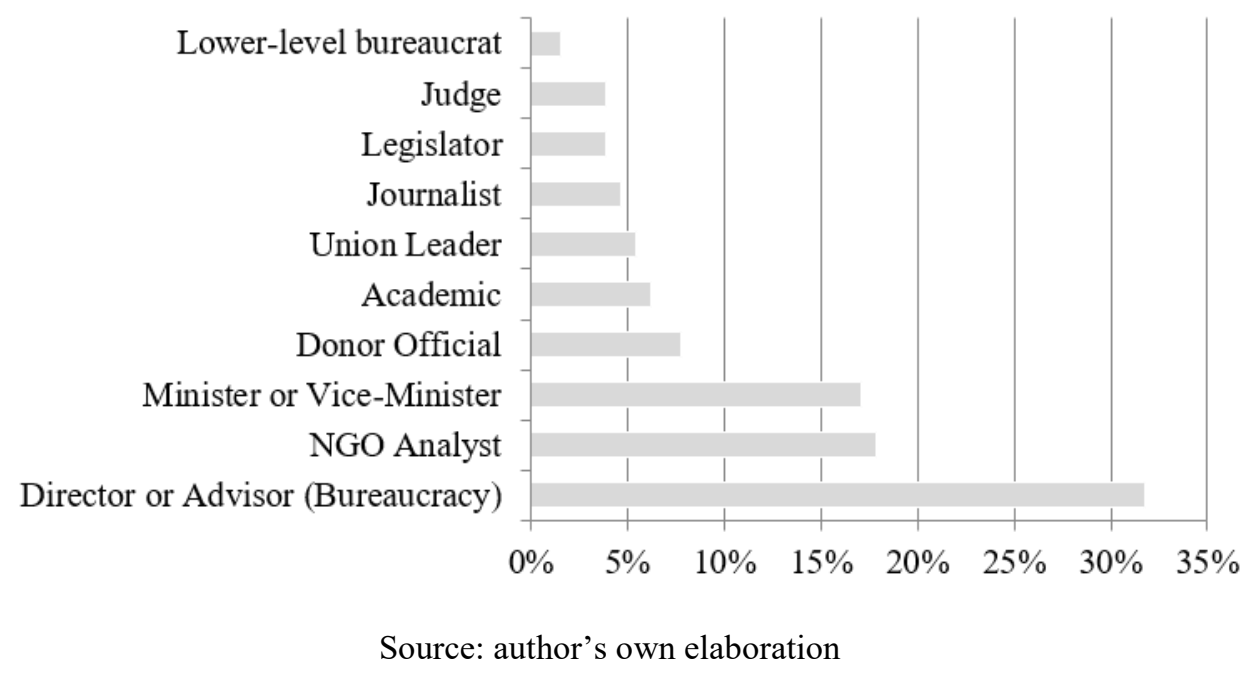

\section{Contrasting Merit Legislation in Paraguay and the DR}

When Lugo and Fernández came to power, neither Paraguay nor the DR had legal merit requirements in force. The DR's 1991 civil service and administrative career law was constitutionally overridden: the President retained a prerogative to appoint at will at all levels (Congreso Nacional de la República Dominicana. 1991; Strazza 2012). Paraguay’s 2000 public service law in turn saw 800 to 1,000 constitutional appeals by state institutions and trade unions after its passage (Congreso de la Nación Paraguaya 2000; World Bank 2005). 
The Supreme Court responded by suspending the law - without passing judgment on most appeals to-date. This suspension applies to the appealing institutions, unions and public servants for the articles appealed. The 1970 Civil Servant Statute of the Stroessner dictatorship or, when not applicable, Civil and Labour Codes then reign (Congreso de la Nación Paraguaya 1970; Sosa Arrua 2011). As a complete register of appeals does not exist, which law applies to whom is often uncertain, however (Interview A). In part in response, Presidents refrained from regulating the law through a decree. Without this decree, the law's stipulations - including the merit requirement - are not in force.

During the episodes under study, however, the DR saw a 'normative revolution' in public service (Interview B). A 2008 public service law closed many loopholes of its predecessor and became 'recognized as one of the most solid [merit] laws in the region.' (Interview C; Congreso Nacional de la República Dominicana 2008). Moreover, the 2010 Constitution restricted presidential patronage to top-level appointees and established a constitutional merit requirement for access to public service (Congreso Nacional de la República Dominicana 2010).

According to prior studies, merit in practice should thus advance, if at all, in the DR rather than Paraguay. Yet, congruent with the argument in this paper, the opposite occurred.

\section{Spoils under Merit Laws, Meritocracy without Merit Laws}

Official data and expert estimates yield consistent results: merit in practice only advanced in Paraguay.

$\underline{\text { Official Data on Competitive Examinations. }}$

In Paraguay, the number of competitive examinations supervised by the Ministry of Civil Service (Secretaría de la Función Pública, SFP) rose from seven in the country's 
history prior to Lugo to 24,325 under Lugo - roughly 26 percent of all public sector vacancies (figure 7). ${ }^{6}$ Examinations focused on technical-level positions (81 percent). While the majority of vacancies remained available for patronage, reform was substantive in comparative terms. In the U.S., for instance, it took 21 years after the 1883 Pendleton Act to extend the merit service to 50 percent of public service (Johnson and Libecap 1994). By contrast, under Lugo, roughly a quarter of vacancies were professionalized within a four-year administration. $^{7}$

In the DR, however, merit in practice stalled. The Ministry of Public Administration (MAP) supervised competitive examinations to fill 1,820 vacancies - less than one percent of vacancies - under Fernández. ${ }^{8}$

\section{FIGURE 7 Vacancies Filled through Examinations Supervised by Civil Service Agencies}

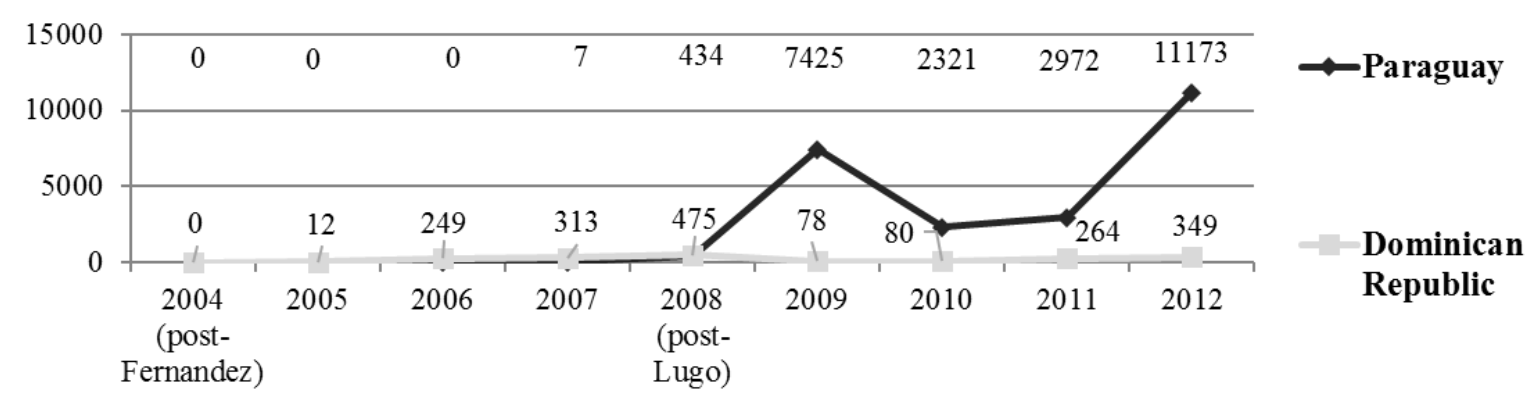

Source: author's own elaboration, based on data in MAP (2013), SFP (2013) and Participación Ciudadana (2007)

\section{Expert estimates.}

To counteract façade meritocracies, civil service ministries in the two countries introduced safeguards in examinations: numerical codes to applicants to assure initial anonymity in candidate evaluation; exam juries with diverse stakeholders, including union representatives; a requirement for multiple sources of evidence, including resume evaluations, interviews, technical exams and personality questionnaires (MAP 2009; SFP 2008); and a requirement for civil service agency ratification at the end (Paraguay) or every 
stage of selection (DR) (Strazza 2012; Interview D). This was more than a formality. In the DR, for instance, 46 percent of selected candidates were rejected in 2005-06 (calculated from Participación Ciudadana 2007). As a Ministry of Public Administration director (Interview E) explains, 'of course we are overloaded with [revision] work, but this is a guarantee that the selection is made adequately.'

Expert estimates mirror the differential number of examinations supervised by civil service agencies. In Paraguay, experts estimated the share of vacancies filled through substantively competitive examinations at 22 percent under Lugo, up from four percent in the preceding Duarte Presidency. In the DR, this share increased only marginally, from five percent (2000-2004 Mejía administration) to eight percent under Fernández (figure 8). The minor increase under Fernández is not statistically significant when applying an adjusted Wald test. In contrast, the increase under Lugo is significant at the 1 percent level. ${ }^{9}$

FIGURE 8 Expert Estimates: Share of Vacancies Filled through Substantively Competitive Examinations

Dominican Republic

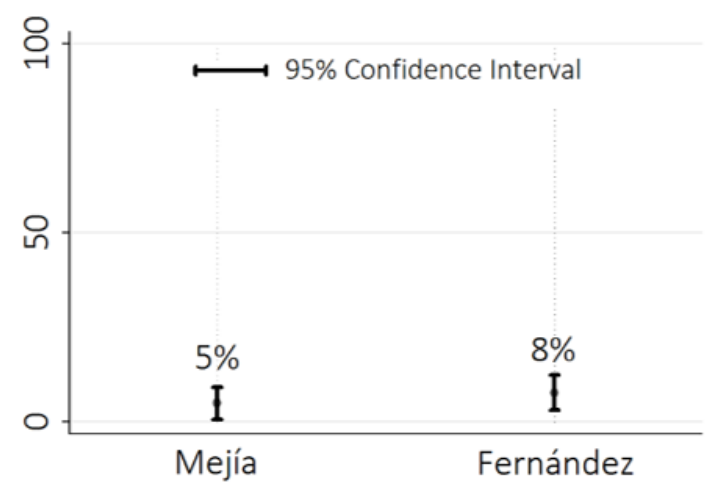

Paraguay

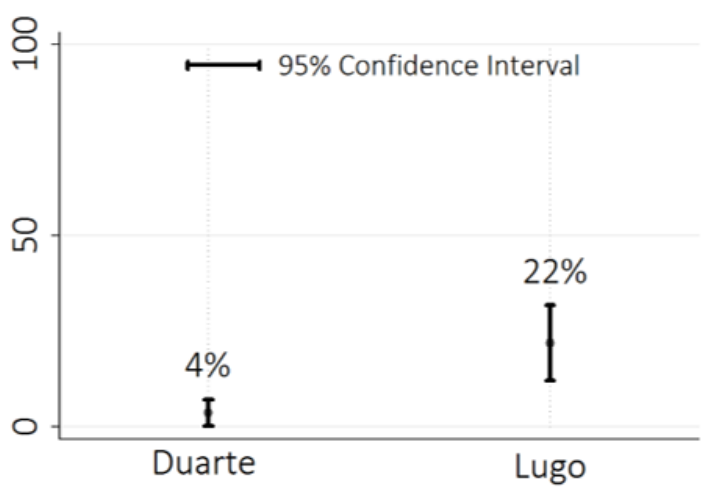

Source: author's expert survey

Other evidence enhances confidence in expert estimate validity. In Paraguay, opposition parties took examinations seriously as job opportunities for affiliates, offering training courses in party offices to prepare members for examinations (Interview F). Moreover, 
formal complaints were filed against less than 0.5 percent of examinations supervised by the SFP (Interview G). By contrast, in the DR, even Fernández' director of the national council for state reform (Interview H) concluded that 'they undertake competitive processes, but at the end the position is awarded to whom the incumbent wants - and, at the moment of decision-making, the party criteria are of weight ... it is a disgrace.' Unsurprisingly, 'citizens, generally speaking, do not trust this selection process. They understand that it is a politicized process. When state institutions seek to recruit via public examinations, they often have to repeat the process two or three times as they frequently do not receive applications, because people say: 'ah, they call for an examination, but already have whom to select there.' (Interview I) This is reflected in a low average number of applicants -2.7 per vacancy despite a public sector wage premium (based on 2007-12 data provided by MAP). Triangulation thus suggests that meritocracy in practice advanced only marginally in the DR, yet not Paraguay.

The implications are clear. Congruent with the argument presented, merit laws were found to be neither sufficient (DR) nor necessary (Paraguay) for merit in practice. The validity of the theorized underlying mechanisms is examined next.

How Meritocracy Stalls in Practice despite Merit Laws: Evidence from the DR. The Dominican case suggests that all four mechanisms identified in prior studies may, concurrently, delink merit laws from merit practice.

First, capacity limitations complicated translating legal merit obligations into practice. To illustrate, a hiring manager (Interview J) lamented:

'You know how much time I have been waiting for four [staff] to be selected by a competitive examination? Seven months ... because I am respecting all the 
steps at the pace at which the Ministry of Public Administration can go forward.'

Moreover, even the DR's 'good practice' law did not manage to close all patronage loopholes. The law only mandated competitive examinations for career positions; institutions responded by recruiting into temporary positions or permanent positions in hierarchies below the career (Interview K).

In the DR's weak rule-of-law context, institutions could also simply violate the law. Temporary patronage appointees were incorporated into permanent career positions, for instance - despite a legal prohibition. As a MAP vice-minister (Interview K) lamented, 'no competitive examinations were undertaken, but nonetheless they contracted personnel extraofficially ... which [then] stays for 10 years.'

Lastly, even where examinations occurred, they were vulnerable to manipulation (Interviews $\mathrm{L}, \mathrm{M}, \mathrm{N}, \mathrm{O}$ and $\mathrm{P}$ ). To name a few: terms of reference were tailored to preferred candidates; vacancy dissemination restricted to party members and friends; exam materials leaked; interview evaluations skewed; competing candidates excluded due to 'losses' of their applications; or candidates other than examination winners recruited.

As a consequence, 'the public service law until now remains a myth. It is constitutional and administrative poetry.' (Interview Q)

\section{$\underline{\text { How Meritocracy Advances in Practice Without Merit Laws: Evidence from Paraguay. }}$}

By contrast, in Paraguay, no law requiring merit was in force. The 2000 public service law was suspended, and Lugo's minority position in parliament coupled with opposition party antagonism to state reforms precluded the passage of legal reform (Schuster, 2015). With the 2000 public service law suspended, the 1970 civil servant statute from the Alfredo Stroessner 
Dictatorship (1954-1989) and - for staff and institutions not governed by the statute - the civil and labour codes, among others, applied (Sosa Arrua, 2011).

None of these statutes explicitly prohibited merit in practice. In fact, even Stroessner's 1970 statute established that administrative career recruitment was to be 'subject to prior verification of ... capacity and aptitudes.' (Congreso de la Nación Paraguaya 1970, p. 2) The statute did not require fair and open competition, advertised vacancies or the recruitment of the best available candidate. As such, it fell short of a legal merit requirement as understood in this paper and, typically, by practitioners and scholars (see, among many, Grindle 2012; UK Civil Service Commission 2012). Yet, the statute was permissive of merit examinations.

With legislation permitting - yet not demanding - merit in practice, the second theorized causal mechanism to account for merit in practice without merit legislation was activated: Paraguayan reformers could exploit legal permissiveness to advance merit in practice. As a minister of civil service (Interview R) explained, 'seeing that the law permits the process of professionalization ... I saw ... very few problems with the law.' (emphasis added by the author) The rationale is simple. The Ministry of Civil Service could draw on legal permissiveness to "work with a lot of force with those institutions willing [to advance merit]' - even while being unable to mandate compliance (Interview S). It did so by issuing a ministerial resolution in the first month of the Lugo Presidency which detailed procedures for meritocratic examinations in line institutions (SFP 2008). Subsequently, the Ministry offered technical assistance and supervision to line institutions for the application of examination procedures. Line ministries were not bound by this resolution by the Ministry of Civil Service: it was optional for them to implement it in practice.

A legal obligation to introduce merit-based personnel practices - in the form of new merit legislation or a lifting of court suspensions of existing legislation - would have not altered this voluntary cooperation scenario in practice, however. As the DR case illustrated, 
compliance with merit laws is de facto optional even if de jure required in patronage states. Arguably, a legal prohibition of meritocracy would have not altered the Paraguayan scenario, either. In Paraguay's weak rule of law context, Paraguayan reformers could have chosen not to comply just as the country's patronage politicians routinely choose not to comply with other public sector legislation (Nickson and Lambert, 2002).

The absence of merit legislation thus did not alter Lugo's possibility frontier for - or ability to advance - patronage and merit in practice.

This is not to say that reform without legislation was Lugo's first choice. The Lugo administration did seek to reform the 2000 public service law, yet its legislative minority position precluded passage (Schuster, 2015). As theorized, the Lugo administration was nonetheless able to advance to merit in practice, and did so from the first month in office. While this explains why Lugo advanced merit in practice without legal reform, it leaves unanswered the separate empirical question why Lugo advanced merit at all. As detailed in Schuster (2015), merit legislation had little to do with this. Instead, political incentives loomed large: reform mobilized political support from voters who valued improved public service delivery, while depriving political opponents of patronage access.

The case comparison thus provides evidence for both the paper's argument - merit laws are neither sufficient nor necessary for merit in practice - and its underlying mechanisms.

\section{Implications for Scholars and Practitioners}

With the rise of the good governance agenda, merit-based civil service legislation has - as evidenced in this paper - proliferated since the 1990s. This has been paralleled by the spread of other good governance legislation, from freedom of information to anti-corruption laws, among many (see, e.g., Berliner, 2014). It is, by now, axiomatic to note that such legislation is by itself insufficient to bring about public sector reform in practice - and this paper has 
added large- and small-n evidence for the case of civil service legislation to this end. Progress towards merit in practice in the cross-country dataset, for instance, has been much less farreaching than progress towards merit legislation over the last forty years.

At the same time, conventional scholarly and practitioner wisdom holds that public sector reform legislation is a necessary first step to bring about reform in practice. Taken at face value, this suggests reformers need to adopt legislation before seeking reform in practice.

Focusing on merit-based civil service legislation, this paper has challenged this reasoning: legal reforms need not come first. Instead, merit legislation leaves incumbent possibility frontiers for patronage and meritocracy in practice unaffected in patronage states. As such, reformers may advance merit in practice with and without merit legislation. Large-n and small-n evidence support this assertion. Data from an original merit law dataset suggests that countries may introduce merit in practice without merit legislation. And the Paraguayan case illustrates that reformers may advance merit in practice even when they are unable to introduce merit legislation and thus demand legal compliance.

The evidence also suggests this reform sequencing is the exception: reformers tend to introduce legislation before reform in practice. On occasion, however, reform in practice happens without legal reform.

While the weight of the evidence thus remains stronger for the insufficiency of legislation, the cases of reform in practice without law suggest a broader, tentative implication for good governance legislation: incumbents may advance good governance practices in patronage states irrespective of good governance laws. Somewhat ironically, the absence of one important good governance dimension - a strong rule of law - implies that outlawing bad and good governance practices is often ineffectual in patronage states. Instead, with informal institutionality prevalent, an incumbent's possibility frontier for good and bad 
governance practices is unaffected by formal legislation. It remains for future research to explore whether this proposition about the unexpected governance benefits of informal institutionality travels empirically beyond merit-based civil service management to other dimensions of good governance.

Lastly, it is worth re-emphasizing that the paper's conclusion about the lack of necessity of merit laws does not imply that such laws - or good governance laws more generally - have no causal efficacy. Whether they do is a separate empirical question. The lack of necessity of merit legislation for merit in practice does suggest, however, that causal efficacy cannot be taken for granted. Yet, numerous large-n studies in the existing literature do just that, measuring merit reforms - or the tying of successors' patronage hands - with merit legislation or boards (Grzymala-Busse 2007; Kostadinova 2012; Neshkova and Kostadinova 2012; Rauch 1995; Ruhil 2003; Ruhil and Camões 2003; Ting, Snyder, Hirano and Folke, 2013). Assessing whether this approach is empirically valid - and merit laws are efficacious in bringing about merit reform in practice - is a fruitful avenue for future research. 


\section{Appendix: Coding Procedure of Merit-Based Civil Service Legislation}

\section{Coding Criteria:}

Countries were coded as having merit-based civil service legislation in a given year if:

1. They had a civil service law on the books

2. And this legislation contained at least one of the following explicit requirements:

a. To select public servants through open and/or public competitions

b. To select public servants solely based on merit and/or their professional qualifications

c. To select public servants based on merit and/or their professional qualifications, while prohibiting the selection of candidates based on favouritism or patronage

When these criteria applied, countries were nonetheless not coded as having merit laws if:

1. Other selection criteria could override merit. To illustrate, where the law introduced a merit requirement, yet also quotas for ethnic minorities, the law was not coded as merit-based if it provided incumbents with discretion in deciding which ethnic minority applicant to hire. The merit requirement was maintained, however, when the law required incumbents to select among members of the quota group based on merit.

2. The merit requirement was waived for a percentage of applicants or for applicants with certain qualifications.

3. Civil service legislation only demanded that recruits count on the requisite qualifications and/or pass an (uncompetitive) examination - rather than win an open competition with other candidates and/or be hired solely based on merit.

4. The merit requirement was not included in legislation but only lower-ranking decrees. 


\section{Coding Procedure.}

Each legislation was independently coded by both a research assistant and the author. In the select cases in which the coding diverged, a consensus was sought. If a consensus could not be reached or the law's phrasing precluded unambiguous coding, the data was coded as missing in the dataset instead.

For 81 percent of the 4174 country-year observations, the data source for the coding was the legislation itself. Copies of relevant laws were either found online through Google searches or requested from the International Labour Organization's (ILO) NATLEX database team. The remaining 19 percent of country-year observations were based on secondary sources. Secondary sources served largely to verify the lack of any civil service legislation (16 percent of country-year observations). For three percent of country-year observations, secondary sources were sufficiently precise - typically by citing civil service legislation which was otherwise unavailable - to enable the coding of legal merit requirements. 


\begin{abstract}
Notes
${ }^{1}$ Professional states vary in the criteria prioritized in competitive examinations, be these academic credentials, professional skills or work experience, for instance (Evans 1998, p. 71). The argument in this paper is unaffected by this variation.

${ }^{2}$ For a recent review of the range of incentives which may underlie merit reforms, see Schuster (2016).

${ }^{3}$ The indicator is coded on a 0 to 5 scale, but transformed to an interval-level estimate with Bayesian item response theory modeling techniques building on inter-coding reliability tests. ${ }^{4}$ This analysis is not without limitations: improvements in impartiality in 1975-2015 may not stem from meritocracy. The V-Dem analysis thus provides only suggestive evidence. ${ }^{5}$ Paraguay’s 2000 Public Service Law has been constitutionally challenged. Uganda’s 1969 and 2008 Public Service Acts delegate recruitment conditions to a Public Service Commission, without stipulating a merit requirement in law. Senegal's 1961 General Public Servant Statute (and its subsequent revisions) foresees competitive examinations, but also permits direct recruitment based on credentials. Iceland's 1996 Government Employees Act requires the public advertisement of vacancies, but delegates selection methods to line ministries.

${ }^{6}$ See Schuster (2015, p. 103) for details on this data and its limitations.

${ }^{7}$ Congruent with the theoretical argument, measurement focuses on the introduction of meritocratic examinations, not their sustainability. In Paraguay, sustainability is yet to be determined. Examinations were largely suspended under President Federico Franco (20122013), yet expanded to over 25,000 vacancies in the first two years of the Horacio Cartes (2013-2018) administration (SFP 2015).

${ }^{8}$ As a caveat, examinations with civil service agency supervision were not the only ones administered. Exams without such supervision took place occasionally for professional
\end{abstract}


groups such as teachers, judges, diplomats and the police and autonomous institutions such as Central Banks and tax agencies (see Schuster 2015, p. 106). Yet, without civil service agency supervision, such examinations were, as illustrated in the text, often vulnerable to manipulations.

${ }^{9}$ The Paraguayan test yielded a p-value of 0.001 with 86 degrees of freedom (df); the DR test yielded a p-value of 0.374 with $98 \mathrm{df}$. The statistical results in figure 8 should be interpreted with caution: they assume an approximate normal distribution. As detailed, experts were not sampled randomly and independently, but rather purposively and through chain referral; as such, the normal distribution assumption may not hold.

${ }^{10}$ That examinations in the DR remained marginal in number and were subject to manipulation is not to say that they had no effect when they occurred. In fact, Oliveros and Schuster (2017) show that merit recruits are more motivated to work hard, less corrupt and less likely to engage in clientelism in the DR. 


\section{References}

Andrews, Matt. 2013. The Limits of Institutional Reform in Development: Changing Rules for Realistic Solutions. Cambridge: Cambridge University Press.

Berliner, Daniel. 2014. 'The Political Origins of Transparency.' The Journal of Politics $76(2), 479-491$

Charron, Nicholas, Carl Dahlström, Mihaly Fazekas and Victor Lapuente. 2016. 'Careers, Connections, and Corruption Risks: Investing the Impact of Bureaucratic Meritocracy on Public Procurement Processes.' The Journal of Politics, early view

Charron, Nicholas, Carl Dahlström and Victor Lapuente. 2012. 'No law without a state.' Journal of Comparative Economics 40(2),176-193.

Comparative Constitutions Project (CCP). 2015. 'Characteristics of National Constitutions, Version 2.0.' Available online at http://comparativeconstitutionsproject.org/ccp-data$\underline{\text { downloads/ }}$

Congreso de la Nación Paraguaya. 1970. Ley N²00/70 Que Establece El Estatuto Del Funcionario Público. [Law No. 200/70 which Establishes the Statute of the Public Servant] Asunción: Congreso de la Nación Paraguaya.

Congreso de la Nación Paraguaya. 2000. Ley $N^{o}$ 1626/2000 De la Función Pública. [Law 1626/2000 of the Public Service] Asunción: Congreso de la Nación Paraguaya. 
Congreso Nacional de la República Dominicana. 1991. Ley No.1491 de Servicio Civil y Carrera Administrativa [Law No. 1491 of the Civil Service and Administrative Career]. Santo Domingo: Congreso Nacional de la República Dominicana

Congreso Nacional de la República Dominicana. 2008. Ley No. 41-08 de Función Pública y crea la Secretaría de Estado de Administración Publica [Law No. 41-08 of the Public Service and which Creates the State Secretary of Public Administration]. Santo Domingo: Congreso Nacional de la República Dominicana

Congreso Nacional de la República Dominicana. 2010. Constitución Política de la República Dominicana. [Political Constitution of the Dominican Republic] Santo Domingo: Congreso Nacional de la República Dominicana.

Coppedge, Michael, John Gerring, Staffan Lindberg, Daniel Pemstein, Svend-Erik Skaaning, Jan Teorell, Eitan Tzelgov, Yi-ting Wang, David Altman, Michael Bernhard, Steven Fish, Adam Glynn, Allen Hicken, Carl Knutsen, Kelly McMann, Megan Reif, Jeffrey Staton, Brigitte Zimmerman. 2016. Varieties of Democracy: Methodology v5. Varieties of Democracy (V-Dem) Project.

Cornell, Agnes and Victor Lapuente. 2014. 'Meritocratic administration and democratic stability.' Democratization 21(7),1286-1304.

Dahlberg, Stefan, Carl Dahlström, Petrus Sundin and Jan Teorell. 2013. 'The Quality of Government Expert Survey 2008-2011: A Report.' University of Gothenburg: The Quality of Government Institute 
Dahlström, Carl, Victor Lapuente and Jan Teorell. 2012. 'Public administration around the world.' In Good Government: The Relevance of Political Science, eds. Sören Holmberg and Bo Rothstein. Cheltenham: Edward Elgar, 13-39.

Dahlström, Carl, Victor Lapuente and Jan Teorell. 2011. 'The Merit of Meritocratization: Politics, Bureaucracy, and the Institutional Deterrents of Corruption.' Political Research Quarterly 65(3), 656-668.

Dahlström, Carl, Teorell, Jan, Dahlberg, Stefan, Hartmann, Felix and Lindberg, Annika. 2015. 'The QoG Expert Survey Dataset II.' University of Gothenburg: The Quality of Government Institute

Evans, Peter 1998. 'Transferable Lessons? Re-Examining the Institutional Prerequisites of East Asian Economic Policies.' Journal of Development Studies 34(6),66-86.

Evans, Peter and James Rauch. 1999. 'Bureaucracy and Growth: A Cross-National Analysis of the Effects of 'Weberian' State Structure on Economic Growth.' American Sociological Review 64(5),748-765.

Fukuyama, Francis. 2014. Political Order and Political Decay: From the Industrial Revolution to the Globalization of Democracy. London: Profile Books.

Goetz, Klaus. 2001. 'Making sense of post-communist central administration: modernization, Europeanization or Latinization?' Journal of European Public Policy 8(6),1032-1051. 
Grindle, Merilee. 2010. 'Constructing, Deconstructing and Reconstructing Career Civil Service Systems in Latin America.' Harvard Kennedy School of Government Faculty Research Working Paper Series RWP 10-025

Grindle, Merilee. 2012. Jobs for the Boys: Patronage and the State in Comparative Perspective. Cambridge: Harvard University Press.

Grzymala-Busse, Anna. 2007. Rebuilding Leviathan: Party Competition and State Exploitation in Post-Communist Democracies. Cambridge: Cambridge University Press.

Helmke, Gretchen and Levitsky, Steven. 2006. Informal Institutions and Democracy: Lessons from Latin America. Baltimore: Johns Hopkins University Press

Henderson, Jeffrey, David Hulme, Hossein Jalilian and Richard Philips. 2007. 'Bureaucratic Effects: 'Weberian' State Structures and Poverty Reduction.' Sociology 41(3), 515-532

Johnson, Ronald and Gary Libecap. 1994. The Federal Civil Service System and The Problem of Bureaucracy. Chicago: University of Chicago.

Kostadinova, Tatiana. 2012. Political Corruption in Eastern Europe: Politics After Communism. Boulder: Lynne Rienner Publishers.

Lapuente, Victor and Marina Nistotskaya. 2009. 'To the Short-Sighted Victor Belong the Spoils: Politics and Merit Adoption in Comparative Perspective.' Governance 22(3),431-458. 
Levitsky, Steven and Maria Murillo. 2013. 'Building Institutions on Weak Foundations.' Journal of Democracy 24(2),93-107.

MAP. 2009. 'Reglamento de Reclutamiento y Selección de Personal en la Administración Pública.' [Regulation of Recruitment and Selection of Personnel in the Public Administration] Available online at http://www.hacienda.gov.do/transparencia/02marco_legal_sistema_transparencia/02decretor/ Decreto\%20No.\%2052409\%20Reglamento\%20de\%20Reclutamiento\%20y\%20Selecci\%C3\%B3n\%20d.pdf

MAP. 2013. 'Concursos 2007-2013 Hasta Junio 10.’ [Competitive Examinations 2007-2013 Until June 10] Santo Domingo: Ministerio de Administración Pública (MAP).

Meyer-Sahling, Jan-Hinrik. 2006. 'The Institutionalization of Political Discretion in PostCommunist Civil Service Systems: The Case of Hungary.' Public Administration 84(3),693715.

Müller, Wolfgang. 2000. 'Patronage by National Governments.' In The Nature of Party Government, eds. Jean Blondel and Maurizio Cotta. New York: Palgrave, 141-160.

Neshkova, Milena and Tatiana Kostadinova. 2012. 'The Effectiveness of Administrative Reform in New Democracies.' Public Administration Review 72(3),324-333.

Nickson, Andrew and Peter Lambert. 2002. 'State Reform and the 'Privatized State' in Paraguay.' Public Administration and Development (22),163-174 
Oliveros, Virginia and Christian Schuster. 2017. 'Merit, Tenure and Bureaucratic Behavior: Evidence from a Conjoint Experiment in the Dominican Republic.', Comparative Political Studies, forthcoming

Participación Ciudadana. 2007. ‘Segundo Informe Alternativo De Organizaciones De La Sociedad Civil Sobre La Aplicación De La Convención Interamericana Contra La Corrupción.' [Second Alternative Report of Civil Society Organizations about the Application of the Inter-American Anti-Corruption Convention] Available online at http://www.oas.org/juridico/spanish/mesicic2_repdom_inf_sc_sp.pdf

Polidano, Charles. 2001. 'Why Civil Service Reforms Fail.' Public Management Review 3(3) $345-36$

Pritchett, Lant, Woolcock, Michael and Matt Andrews. 2010. 'Capability Traps? The Mechanisms of Persistent Implementation Failure.' Center for Global Development Working Paper 234, December 2010

Rauch, James. 1995. 'Bureaucracy, Infrastructure, and Economic Growth: Evidence from U.S. Cities During the Progressive Era.' The American Economic Review 85(4),968-979.

Ruhil, Anirudh. 2003. 'Urban Armageddon or Politics as Usual? The Case of Municipal Civil Service Reform.’ American Journal of Political Science 47(1),59-170.

Ruhil, Anirudh and Pedro Camões. 2003. 'What Lies Beneath: The Political Roots of State Merit Systems.' Journal of Public Administration Research and Theory 13(1), 27-42. 
Schuster, Christian. 2015. 'When the Victor Cannot Claim the Spoils: Institutional Incentives for Professionalizing Patronage States.' PhD Thesis. Department of Government. London: The London School of Economics and Political Science (LSE).

Schuster, Christian. 2016. 'What Causes Patronage Reform? It Depends on the Type of Civil Service Reform.' Public Administration, 94(4), 1094-1104

SFP. 2008. 'Resolución SFP No 50/2008.' [SFP Resolution No. 50/2008] Available online at http://www.mec.gov.py/talento/Normativas/resolucionsfp50.pdf

SFP. 2013. 'Concursos Realizados Entre 2008 y 2012 con Acompañamiento y Monitoreo de la SFP.' [Competitive Examinations Undertaken between 2008 and 2012 with Assistance and Supervision by the SFP] Asunción: Secretaría de la Función Pública (SFP).

SFP. 2015. 'Informe de Gestión: Agosto 2013 - Agosto 2015.' [Management Report: August 2013 - August 2015] Asunción: Secretaría de la Función Pública (SFP).

Sosa Arrua, Enrique. 2011. 'Reforma del servicio civil. Desvinculación del Personal Público en el Paraguay.' Available online at http://www.cadep.org.py/uploads/2011/03/NOTA-1Enrique-Sosa.pdf

Strazza, Luciano. 2012. 'República Dominicana.' In Informe Barometro de la profesionalización del empleo público en Centroamérica y República Dominicana No. 2 [Barometer of the Professionalization of Public Employment in Central America and the Dominican Republic], ed. Francisco Longo. Santo Domingo: AECID, FLACSO and SICA, $25-64$ 
Ting, Michael, James Snyder, Shigeo Hirano and Olle Folke. 2013. 'Elections and reform: The adoption of civil service systems in the U.S. states.' Journal of Theoretical Politics 25(3),363-387.

UK Civil Service Commission. 2012. 'Recruitment Principles.' Available online at http://civilservicecommission.independent.gov.uk/wp-content/uploads/2012/04/RecruitmentPrinciples.pdf

Verheijen, Tony. 2000. 'Administrative Capacity Development: A Race Against Time?' Working Document W 107. The Hague: Scientific Council for Government Policy.

World Bank. 2005. Republic of Paraguay Institutional and Governance Review - Breaking with Tradition: Overcoming Institutional Impediments To Improve Public Sector Performance. Washington DC: World Bank.

World Bank. 2008. Public Sector Reform: What Works and Why? - An IEG Evaluation of World Bank Support. Washington DC: World Bank. 


\section{Interviews}

Interview A, Judge, Superior Tribunal of Electoral Justice (TSJE), Asunción, Paraguay, November 1, 2012

Interview B, Director, Ministry of Public Administration (MAP), Santo Domingo, Dominican Republic, April 25, 2013

Interview C, Secretary General, Latin American Center for Development Administration (CLAD), Santo Domingo, Dominican Republic, June 11, 2013

Interview D, Director, Ministry of Civil Service (SFP), Asunción, Paraguay, October 25, 2012

Interview E, Director, Ministry of Public Administration (MAP), Santo Domingo, Dominican Republic, April 24, 2013

Interview F, Vice-Minister of Education, Asunción, Paraguay, November 19, 2012

Interview G, Director, Ministry of Civil Service (SFP), Asunción, Paraguay, November 9, 2012

Interview H, Director, National Council for State Reform (CONARE), Santo Domingo, Dominican Republic, April 11, 2013

Interview I, Analyst, NGO, Santo Domingo, Dominican Republic, April 17, 2013

Interview J, Director, Presidency, Santo Domingo, Dominican Republic, April 24, 2013

Interview K, Vice-Minister, Ministry of Public Administration, Santo Domingo, Dominican Republic, April 24, 2013 
Interview L, Advisor, Ministry of Public Administration, Santo Domingo, Dominican Republic, April 24, 2013

Interview M, Director, Ministry of Education, Santo Domingo, Dominican Republic, June 21, 2013

Interview N, Analyst, NGO, Santo Domingo, Dominican Republic, June 7, 2013

Interview O, Leader, Public Sector Union, Santo Domingo, Dominican Republic, April 16, 2013

Interview P, Director, Ministry of Health, Santo Domingo, Dominican Republic, April 12, 2013

Interview Q, Analyst, NGO, Santo Domingo, Dominican Republic, April 16, 2013

Interview R, Minister, Ministry of Civil Service (SFP), Asunción, Paraguay, November 7, 2012

Interview S, Minister, Ministry of Civil Service (SFP), Asunción, Paraguay, November 26, 2012 